\title{
Metabolic syndrome among type 2 diabetic patients in Sub-Saharan African countries: a systematic review and meta-analysis
}

\section{Authors}

Wondimeneh shibabaw shiferaw, BSc, MSc ${ }^{*} *$ Corresponding author Department of Nursing, College of Health Science, Debre Berhan University Address: P.O. Box 445, Debre Berhan University, Ethiopia; Email: wshibabaw2015@gmail.com Tadesse Yirga Akalu, BSc, MSc

Department of Nursing, College of Health Science, Debre Markos University Address: P.O. Box 269, Debre Markos, Ethiopia; Email: tadesseyirga680@ gmail.com

Mihretie Gedefaw , BSc, MSc

Department of Nursing, College of Health Science, Debre Markos University Address: P.O. Box 269, Debre Markos, Ethiopia; Email: mihretie23@gmail.com Yared Asmare Aynalem, BSc, MSc

Department of Nursing, College of Health Science, Debre Berhan University

Address: P.O. Box 445, Debre Berhan University, Ethiopia; Email: yaredasmare123@gmail.com

\section{Denis Anthony, Professor}

Health and Social Care Research Centre, University of Derby and Emeritus Professor, School of Healthcare, University of Leeds ;Email: D.Anthony@ derby.ac.uk

Ayelign Mengesha, BSC, MSC

Department of nursing, College of health science, Wolida University, Ethiopia

Email: Ayelignmengesha59@gmail.com

Worku Misganaw, BSC, MSC

Department of Nursing, College of Health Science, Debre Berhan University, Ethiopia

Email: wmisganaw2016@gmail.com

\section{Henok Mulugeta, BSc, MSc}

Department of Nursing, College of Health Science, Debre Markos University

Address: P.O. Box 269, Debre Markos, Ethiopia; Email: mulugetahenok68@ gmail.com

Getenet Dessie, BSc, MSc,

Department of Nursing, School of Health Science, College of Medicine and Health Science, Bahir Dar University

Address: P.O. Box 79, Bahir Dar, Ethiopia; Email: $\underline{\text { ayalew.d16@gmail.com }}$ 
medRxiv preprint doi: https://doi.org/10.1101/2020.05.14.20101410; this version posted May 19, 2020. The copyright holder for this preprint (which was not certified by peer review) is the author/funder, who has granted medRxiv a license to display the preprint in perpetuity.

All rights reserved. No reuse allowed without permission.

\begin{abstract}
Background: Metabolic syndrome is one of the serious public health problems among type 2 diabetic patients. Despite a number of studies have been conducted, there is no overall estimation on the prevalence of metabolic syndrome among type 2 diabetic patients in Sub-Saharan African countries. Therefore, this study aimed to estimate the pooled prevalence of metabolic syndrome in patients with type 2 diabetes mellitus in Sub -Saharan African countries.
\end{abstract}

Methods: PubMed, Web of Science, African Journals Online, Google Scholar, Scopus, and Wiley Online Library databases from inception to April 27, 2020 were searched to identify relevant studies. The $\mathrm{I}^{2}$ statistic was used to check heterogeneity across the included studies. DerSimonian and Laird random-effects model was applied to estimate pooled effect size, and 95\% confidence interval across studies. A funnel plot and Egger's regression test were used to determine the presence of publication bias. Sensitivity analysis was deployed to determine the effect of a single study on the overall estimation. All statistical analyses were done using STATA $^{\mathrm{TM}}$ Version 14 software.

Result: In this meta-analysis, a total of 23 studies with 6,482 study participants were included. The estimated prevalence of metabolic syndrome in Sub-Saharan African countries was 59.62\% (95\% CI: 52.20, 67.03). Based on the subgroup analysis, the highest prevalence of metabolic syndrome $(61.14 \%, 95 \%$ CI: 51.74, 70.53) was reported in Ethiopia. . Additionally, the highest prevalence of metabolic syndrome was reported across studies using the diagnostic criteria of National Cholesterol Education Program Adult Treatment Panel III 64.8\% (95\% CI: 54.74, 74.86), followed by International Diabetic Federation (57.15\%), and World health Organization $(53.12 \%)$ definitions.

Conclusion: Almost two out of three type 2 diabetic patients in Sub-Saharan African countries have metabolic syndrome, which implies that its prevalence is high in patients with T2DM. Therefore, Policymakers $(\mathrm{FMoH})$ need to design efficient strategies and guideline to reduce and control the burden of metabolic syndrome and its impact among diabetic population.

Key words: Metabolic syndrome, Prevalence, Type2 diabetes mellitus, Sub-Saharan Africa 
medRxiv preprint doi: https://doi.org/10.1101/2020.05.14.20101410; this version posted May 19, 2020. The copyright holder for this preprint (which was not certified by peer review) is the author/funder, who has granted medRxiv a license to display the preprint in perpetuity.

\section{Background}

Metabolic syndrome (MetS) is becoming a serious global public health problem [1]. The metabolic syndrome is a clustering of key cardiovascular risk factors and includes abdominal obesity, dyslipidemia, hyperglycemia and hypertension with an individual[2,3]. It is a complex disorder represented by a set of cardiovascular risk factors that are commonly associated with central adiposity and insulin resistance [4]. The magnitude of metabolic syndrome in developing countries is rising due to the global epidemic of obesity and type 2 diabetes mellitus [5, 6]. One study showed that the prevalence of metabolic syndrome was $18 \%$ among adult population in Sub-Saharan Africa [7].

The etiology of metabolic syndrome is complex and rooted in multiple risk factors. Studies suggest that numerous risk factors are responsible for metabolic syndrome in T2DM patients including old age[8-10], obesity [8, 9, 11], waist circumference[8, 12], systolic blood pressure[8, $10,12]$, diastolic blood pressure $[8,10]$, triglyceride $[8,10,12]$, low high density lipoprotein[8, $12,13]$, family history of diabetes [9, 11], female [9, 10, 12], high low density lipoprotein [10], fasting blood sugar [12], upper socioeconomic status and urban[11], and HbA1c values and microalbuminuria[14].

Metabolic syndrome is a group of interconnected clinical and biological abnormalities which leads to cardiovascular diseases (CVDs) $[5,15]$, and it is frequently occurs among people with T2DM [2, 16]. It is an independent clinical indicator of macrovascular and microvascular complications in diabetic patients including coronary heart disease, stroke and other diseases involving the blood vessel. In addition it markedly increases health care cost, cardiovascular mortality, decreased quality of life, and increases the risk of premature death, renal disease, mental disorders and cancer [8, 13, 17-19].

The prevalence of metabolic syndrome in patients with T2DM varies widely across many literatures. For instance, the prevalence of metabolic syndrome is 57\% in India [20], 70.4\% in Iran [21], 84.8 in Malaysia [22], 77.9\% in Korea [23], 51\% Nigeria [24], 46.5\% South Africa [25], 73\% Zambia [26], 43\% Zimbabwe [27], 68.6\% Ghana [28], and 70.1\% in Ethiopia [29]. Though different primary studies in Sub-Saharan African countries showed the prevalence of metabolic syndrome in patients with T2DM, their results have demonstrated substantial variation 
medRxiv preprint doi: https://doi.org/10.1101/2020.05.14.20101410; this version posted May 19, 2020. The copyright holder for this preprint (which was not certified by peer review) is the author/funder, who has granted medRxiv a license to display the preprint in perpetuity.

All rights reserved. No reuse allowed without permission.

regarding its prevalence in the region. Therefore, this study was aimed to estimate the pooled prevalence of metabolic syndrome in patients with T2DM in Sub-Saharan African countries. The findings of this study would serve as a benchmark for policymakers to implement appropriate preventative measures, and to alleviate the double burden of metabolic syndrome.

\section{Methods}

\section{Design and search strategy}

Initially, Joanna Briggs Institute, and PROSPERO databases were searched to check out whether systematic review and meta-analysis is exist or for the presence of ongoing projects related to the current topic. The literatures were searched using PubMed, Scopus, Google scholar, African Journals Online, Web of Science, and Wiley Online Library. Manual search was done for grey literature available on local university shelves and institutional repositories. Moreover, the reference lists of all retrieved articles were conducted to identify additional relevant research to minimize publication bias to possible level. This search involved articles published from inception to April 27, 2020. The search was restricted to full texts, free articles, human studies, and English language publications. Endnote X 8.1 reference manager software was used to search, collect, organize search outcomes and for removal of duplicate articles. The search was conducted using the following medical subject headings (MeSH), and free-text terms: "metabolic syndrome", "syndrome X", "insulin resistance syndrome", "prevalence", "Type 2 diabetes mellitus", "type 2 diabetes", "diabetes Mellitus", "non-insulin dependent diabetes", "adult onset diabetes", "Sub Saharan Africa", and "names of each Sub Saharan Africa countries". Boolean operators like "AND" and "OR" were used to combine search terms (Table 1). 
medRxiv preprint doi: https://doi.org/10.1101/2020.05.14.20101410; this version posted May 19, 2020. The copyright holder for this preprint (which was not certified by peer review) is the author/funder, who has granted medRxiv a license to display the preprint in perpetuity.

All rights reserved. No reuse allowed without permission.

\section{Table 1. Pubmed search history}

Search Search terms Hits

$1 \quad$ Type 2 diabetes mellitus OR type 2 diabetes OR diabetes Mellitus OR non-insulin dependent diabetes OR adult onset diabetes

2 metabolic syndrome OR syndrome X OR insulin resistance syndrome

$3 \quad \# 1$ and \#2

4 African filter $((($ Angola OR Benin OR Botswana OR "Burkina Faso"OR Burundi OR Cameroon OR "Cape Verde" OR"Central African Republic" OR Chad OR Comoros OR Congo OR "Democratic Republic of Congo" OR Djibouti OR"Equatorial Guinea" OR Eritrea OR Ethiopia OR Gabon OR Gambia OR Ghana OR Guinea OR"Guinea Bissau" OR "Ivory Coast" OR "Cote d'Ivoire" OR Kenya OR Lesotho OR Liberia OR Madagascar OR Malawi OR Mali OR Mauritania OR Mauritius OR Mozambique OR Namibia OR Niger OR Nigeria OR Principe OR Reunion OR Rwanda OR"Sao Tome" OR Senegal OR Seychelles OR"Sierra Leone" OR Somalia OR"South Africa" OR Sudan OR Swaziland OR Tanzania OR Togo OR Uganda OR"Western Sahara" OR Zambia OR Zimbabwe OR "Central Africa" OR"Central African" OR"West Africa" OR"West African" OR"Western Africa" OR"Western African" OR "EastAfrica" OR"East African" OR"Eastern Africa" OR "Eastern African" OR "South African" OR"Southern Africa" OR "Southern African" OR"sub Saharan Africa" OR"sub Saharan African" OR"sub Saharan Africa" OR"sub Saharan African" NOT"guinea pig" NOT"guinea pigs" NOT"aspergillus niger" ))))

\section{Eligibility criteria}

Studies were included if they fulfilled the following criteria: (1) All observational studies which report the prevalence of metabolic syndrome in patients with T2DM; (2) articles published in peer-reviewed journals or grey literature; and (3) articles published in English from inception to April 27, 2020. Furthermore, if different diagnostic criteria of MetS were found in a study, our first choice was the National Cholesterol Education Program Adult Treatment Panel (NCEPATP III), and our second choice considered International Diabetes Federation (IDF). Studies were excluded if: (1) they were not fully accessible; (2) they possessed a poor quality score as per the stated criteria; (3) case series, letters, comments and editorials; and/or (4) they failed to measure the desired outcome (i.e., metabolic syndrome).

\section{Outcome of interest}


medRxiv preprint doi: https://doi.org/10.1101/2020.05.14.20101410; this version posted May 19, 2020. The copyright holder for this preprint (which was not certified by peer review) is the author/funder, who has granted medRxiv a license to display the preprint in perpetuity.

All rights reserved. No reuse allowed without permission.

The main outcome of interest was the prevalence of metabolic syndrome in patients with T2DM reported in the original paper both as percentage and as the number of metabolic syndrome (n) / total number of patients T2DM (N). The diagnostic criteria of metabolic syndrome in the current review included; International Diabetes Federation (IDF) [30], World Health Organization (WHO) [31], and the National Cholesterol Education Program Adult Treatment Panel III (NCEP ATP II) [32].

\section{Data extraction and quality assessment}

Two authors independently extracted all necessary data from each study using Microsoft Excel spread sheet. If discrepancies between data extractors were observed, a third author was involved. For each included study, the following data were extracted: corresponding author, publication year, country, study design, sample size, data collection period, sampling technique, metabolic syndrome diagnostic criteria, response rate, and prevalence of metabolic syndrome with its $95 \%$ confidence interval (CI). The methodological quality of each included study was assessed using the Newcastle-Ottawa scale (NOS)[33]. This scale has several key criteria including the representativeness of the sample, response rate, measurement tool used, comparability of the subject, and the appropriateness of the statistical test used to analyze the data. Studies were included in the analysis if they scored $\geq 5$ out of 10 points in three domains of ten modified NOS components for observational studies [34]. Furthermore, quality assurance checks were independently performed by three authors. Any disagreements at the time of data abstraction were resolved by discussion and consensus (Supplementary file 1).

\section{Assessment of risk of bias in included studies}

The risk of bias of selected articles were assessed using the risk of bias tool for prevalence studies developed by Hoy et al. [35]. After reviewing different literatures, we decide that articles scored 8 or more "yes" answers out of ten point scale were considered to be low risk of bias; 6 to 7 "yes" answers were considered as moderate risk of bias; 5 or fewer "yes" answers were considered to be high risk of bias (see supplementary file 2). Two authors carried out the risk of bias assessment of the included studies independently. A summary of the areas considered in the assessment of each domain is included in the risk of bias assessment of included studies. 
medRxiv preprint doi: https://doi.org/10.1101/2020.05.14.20101410; this version posted May 19, 2020. The copyright holder for this preprint (which was not certified by peer review) is the author/funder, who has granted medRxiv a license to display the preprint in perpetuity.

All rights reserved. No reuse allowed without permission.

\section{Heterogeneity and publication bias}

Heterogeneity between study estimates was assessed using the Cochran's Q and the $\mathrm{I}^{2}$ statistic [36]. The $\mathrm{I}^{2}$ statistic estimates the percentage of total variation across studies due to true between-study differences rather than chance. In this study, heterogeneity was interpreted as an $\mathrm{I}^{2}$ value of $0 \%=$ no heterogeneity, $25 \%=$ low, $50 \%=$ moderate, and $75 \%=$ high [37]. In case of high heterogeneity, subgroup analysis to reduce heterogeneity, and meta regression analysis to explore sources of heterogeneity were employed. In addition, potential outliers were investigated in sensitivity analysis by dropping each study at a time. Potential publication bias was assessed by visually inspecting funnel plots and objectively using Egger test $\mathrm{p}<0.05$ were considered as statistical significant publication bias [38]. Trim-and-fill analysis was used to adjust estimates for the effects of publication bias.

\section{Statistical analysis}

To obtain the meta-weighted prevalence of metabolic syndrome among T2DM, a meta-analysis using random-effects model DerSimonian and Laird method was utilised due to significant heterogeneity among studies $\left(\mathrm{I}^{2}=87.8 \%, \mathrm{p}<0.001\right)[39]$. The pooled effect size (i.e. Prevalence) with a 95\% confidence interval (CI) was generated and presented using a forest plot. For pooled data analysis, we merged the estimates of metabolic syndrome by NCEP ATP II, IDF, and WHO definitions criteria (average prevalence across those with multiple definitions). All data manipulation and statistical analyses was performed using the STATA ${ }^{\text {TM }}$ Version 14 software [40].

\section{Presentation and reporting of results}

The results of this review were reported based on the Preferred Reporting Items for Systematic Review and Meta-Analysis statement (PRISMA) guideline[41]. The entire process of study screening, selection, and inclusion were described with the aid of a flow diagram. Results were presented using forest plots and summary tables.

\section{Results}

\section{Search results}


medRxiv preprint doi: https://doi.org/10.1101/2020.05.14.20101410; this version posted May 19, 2020. The copyright holder for this preprint (which was not certified by peer review) is the author/funder, who has granted medRxiv a license to display the preprint in perpetuity.

All rights reserved. No reuse allowed without permission.

Our compressive search strategy owns us a total of 1,325 articles. Of these, 1,318 articles were retrieved from PubMed (81), Scopus (299), Google Scholar (442), Web of Science (96), Wiley Online Library (318), and African Journals Online (159). The remaining 7 were found through a manual search. After excluding duplicate publications, 687 articles remained. About 565 articles were excluded after reading the titles and abstracts based on the pre-defined eligibility criteria. Out of them 122 articles were included and screened for further assessment. Finally, 23 articles included in the analysis (Fig. 1).

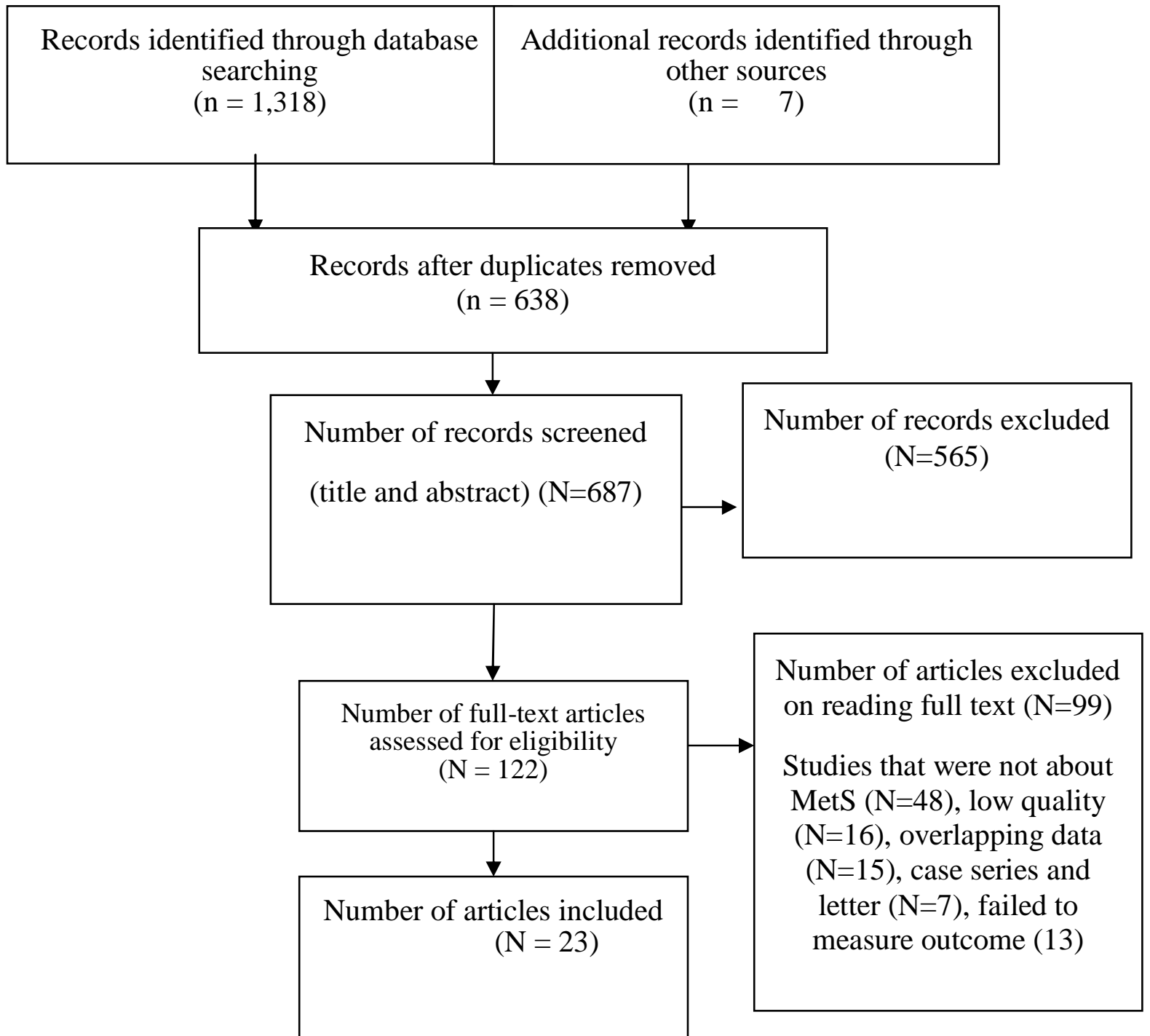

Figure 1. PRISMA flow chart of the study selection 
medRxiv preprint doi: https://doi.org/10.1101/2020.05.14.20101410; this version posted May 19, 2020. The copyright holder for this preprint (which was not certified by peer review) is the author/funder, who has granted medRxiv a license to display the preprint in perpetuity.

\section{Baseline characteristics of the included studies}

The search strategy yields a total of 23 studies for data extraction with a total sample of 6,482 T2DM patients which were found in sub-Saharan Africa. From the studies which included for the final analysis, the majority (95\%) of the studies included were cross-sectional in study design. The total number of participants per study ranged from 103 to 634 . The highest (90.6\%), and the lowest (24\%) prevalence of metabolic syndrome were reported in the studies conducted in Ghana [42, 43]. Four studies were conducted in Ethiopia [29, 44-46], eight in Ghana [42, 43, 4752], seven in Nigeria [11, 24, 53-57], one each from Zambia [26], South Africa [25], Zimbabwe [27], and Cameroon[58]. Regarding the diagnostic criteria used to assess metabolic syndrome in patients with T2DM, five studies [11, 24, 27, 53, 54] used the WHO definition, eight studies $[25,43,44,46,47,49,56,58]$ used IDF, and ten studies [26, 29, 42, 45, 48, 50-52, 55] were used NCEP-ATP III. The quality score of each primary study, based on the Newcastle-Ottawa quality score assessment was moderate to high for all 23 articles assessed. 
Table 2. Baseline characteristics of the included studies

\begin{tabular}{|c|c|c|c|c|c|c|c|c|c|}
\hline Author/s[Reference] & $\begin{array}{l}\text { Publica } \\
\text { tion } \\
\text { year }\end{array}$ & Country & $\begin{array}{l}\text { Study } \\
\text { design }\end{array}$ & $\begin{array}{l}\text { sample } \\
\operatorname{size}(n)\end{array}$ & $\begin{array}{l}\text { Prevalence (\%) } \\
\text { with 95\% CI }\end{array}$ & $\begin{array}{l}\text { Type of } \\
\text { Diagnostic } \\
\text { Criteria } \\
\text { used }\end{array}$ & $\begin{array}{l}\text { sampling } \\
\text { technique }\end{array}$ & study period & $\begin{array}{l}\text { Quality } \\
\text { score } \\
\text { (NOS) }\end{array}$ \\
\hline Abban, H.A., et al.[47] & 2017 & Ghana & $\begin{array}{l}\text { Cross- } \\
\text { sectional }\end{array}$ & 103 & $75(66.64,83.36)$ & IDF & Convenience & March 8 to April 202015 & 6 \\
\hline $\begin{array}{l}\text { Adediran, O., et al } \\
{[24]}\end{array}$ & 2007 & Nigeria & $\begin{array}{l}\text { cross- } \\
\text { sectional }\end{array}$ & 408 & $51(46.15,55.85)$ & WHO & Unspecified & Unspecified & 7 \\
\hline $\begin{array}{l}\text { Agyemang-Yeboah, } \\
\text { F., et al [42] }\end{array}$ & 2019 & Ghana & $\begin{array}{l}\text { cross- } \\
\text { sectional }\end{array}$ & 405 & $90.6(87.76,93.4)$ & $\begin{array}{l}\text { NCEP-ATP } \\
\text { III }\end{array}$ & $\begin{array}{l}\text { Simple } \\
\text { Random } \\
\text { sampling }\end{array}$ & Unspecified & 8 \\
\hline Alebiosu, C.O [53] & 2004 & Nigeria & $\begin{array}{l}\text { cross- } \\
\text { sectional }\end{array}$ & 218 & $25.2(19.44,30.96)$ & WHO & Unspecified & $\begin{array}{lll}\text { September } & 1999 & \text { to } \\
\text { August 2001 } & & \end{array}$ & 6 \\
\hline Biadgo, B., et al [45] & 2018 & Ethiopia & $\begin{array}{l}\text { cross- } \\
\text { sectional }\end{array}$ & 159 & $66.7(59.37,74.03)$ & $\begin{array}{l}\text { NCEP-ATP } \\
\text { III }\end{array}$ & $\begin{array}{l}\text { Systematic } \\
\text { random } \\
\text { sampling }\end{array}$ & June to July, 2015. & 7 \\
\hline Birarra, M.K etal [46] & 2018 & Ethiopia & $\begin{array}{l}\text { cross- } \\
\text { sectional }\end{array}$ & 256 & $57(50.94,63.06)$ & IDF & $\begin{array}{l}\text { Systematic } \\
\text { random } \\
\text { sampling }\end{array}$ & March to 30th May 2017 & 8 \\
\hline Chanda, H., et al.[26] & 2010 & Zambia & $\begin{array}{l}\text { cross- } \\
\text { sectional }\end{array}$ & 400 & $73(68.65,77.35)$ & $\begin{array}{l}\text { NCEP-ATP } \\
\text { III }\end{array}$ & Unspecified & Unspecified & 6 \\
\hline $\begin{array}{l}\text { Gebremeskel, G.G., et } \\
\text { al [44] }\end{array}$ & 2019 & Ethiopia & $\begin{array}{l}\text { cross- } \\
\text { sectional }\end{array}$ & 419 & $51.1(46.31,55.89)$ & IDF & $\begin{array}{l}\text { Systematic } \\
\text { random } \\
\text { sampling }\end{array}$ & February to June 2018 & 8 \\
\hline Isezuo, $S$ etal ,[11] & 2005 & Nigeria & $\begin{array}{l}\text { cross- } \\
\text { sectional }\end{array}$ & 254 & $59.1(53.05,65.15)$ & WHO & Consecutive & January to august 2002 & 6 \\
\hline $\begin{array}{l}\text { Kalk, W. and B. Joffe } \\
\text { [25] }\end{array}$ & 2008 & $\begin{array}{l}\text { South } \\
\text { Africa }\end{array}$ & $\begin{array}{l}\text { cross- } \\
\text { sectional }\end{array}$ & 500 & $46.5(42.13,50.87)$ & IDF & Unspecified & Unspecified & 6 \\
\hline Kengne AP et al. [58] & 2012 & $\begin{array}{l}\text { Cameroo } \\
\mathrm{n}\end{array}$ & $\begin{array}{l}\text { cross- } \\
\text { sectional }\end{array}$ & 308 & $71.7(66.67,76.73)$ & IDF & Consecutive & Unspecified & 7 \\
\hline $\begin{array}{l}\text { Makuyana, D., et al } \\
{[27]}\end{array}$ & 2004 & $\begin{array}{l}\text { Zimbabw } \\
\text { e }\end{array}$ & $\begin{array}{l}\text { cross- } \\
\text { sectional }\end{array}$ & 109 & $43(33.71,52.29)$ & WHO & Convenience & Unspecified & 6 \\
\hline Mogre v.et al [43] & 2014 & Ghana & Cross- & 200 & $24(18.01,29.99)$ & IDF & Convenience & Unspecified & 6 \\
\hline
\end{tabular}




\begin{tabular}{|c|c|c|c|c|c|c|c|c|c|}
\hline & & & sectional & & & & & & \\
\hline Nsiah, K., et al [48] & 2020 & Ghana & $\begin{array}{l}\text { cross- } \\
\text { sectional }\end{array}$ & 150 & $58(50.10,65.90)$ & $\begin{array}{l}\text { NCEP-ATP } \\
\text { III }\end{array}$ & Convenience & February to April 2013 & 6 \\
\hline $\begin{array}{l}\text { Ogedengbe, } \\
\text { etal.[54] }\end{array}$ & 2014 & Nigeria & $\begin{array}{l}\text { case } \\
\text { control }\end{array}$ & 124 & $87.1(81.20,93.00)$ & WHO & Convenience & Unspecified & 7 \\
\hline $\begin{array}{l}\text { Osei-Yeboah, J., et al } \\
\text { [49] }\end{array}$ & 2017 & Ghana & $\begin{array}{l}\text { cross- } \\
\text { sectional }\end{array}$ & 162 & $69.1(62.03,76.25)$ & IDF & Convenience & $\begin{array}{l}\text { February } 2016 \text { and April } \\
2016\end{array}$ & 7 \\
\hline Osuji, C., et al.[55] & 2012 & Nigeria & $\begin{array}{l}\text { cross- } \\
\text { sectional }\end{array}$ & 118 & $66.7(58.20,75.20)$ & $\begin{array}{l}\text { NCEP-ATP } \\
\text { III }\end{array}$ & Convenience & Unspecified & 6 \\
\hline Puepet, F., et al.[56] & 2009 & Nigeria & $\begin{array}{l}\text { cross- } \\
\text { sectional }\end{array}$ & 634 & $63.6(59.85,67.35)$ & IDF & Consecutive & $\begin{array}{lr}\text { January } 2006 & \text { and } \\
\text { December } & 2008\end{array}$ & 8 \\
\hline Titty, F [50] & 2009 & Ghana & $\begin{array}{l}\text { cross- } \\
\text { sectional }\end{array}$ & 300 & $60.3(54.76,65.84)$ & $\begin{array}{l}\text { NCEP-ATP } \\
\text { III }\end{array}$ & Consecutive & June 2006 to May 2007 & 7 \\
\hline Titty, F [51] & 2010 & Ghana & $\begin{array}{l}\text { cross- } \\
\text { sectional }\end{array}$ & 240 & $43.3(37.03,49.57)$ & $\begin{array}{l}\text { NCEP-ATP } \\
\text { III }\end{array}$ & Unspecified & $\begin{array}{lll}\text { September } & 2006 & \text { to } \\
\text { August 2007 } & & \end{array}$ & 6 \\
\hline Titty, F.-V.K etal [52] & 2008 & Ghana & $\begin{array}{l}\text { cross- } \\
\text { sectional }\end{array}$ & 456 & $55.9(51.34,60.46)$ & $\begin{array}{l}\text { NCEP-ATP } \\
\text { III }\end{array}$ & Consecutive & $\begin{array}{l}\text { January } 2006 \text { to May } \\
2007\end{array}$ & 8 \\
\hline Unadike, B., et al.[57] & 2009 & Nigeria & $\begin{array}{l}\text { cross- } \\
\text { sectional }\end{array}$ & 240 & $62.5(56.38,66.62)$ & $\begin{array}{l}\text { NCEP-ATP } \\
\text { III }\end{array}$ & Unspecified & January to August, 2008 & 7 \\
\hline Woyesa, S.B etal. [29] & 2017 & Ethiopia & $\begin{array}{l}\text { cross- } \\
\text { sectional }\end{array}$ & 319 & $70.1(65.06,75.12)$ & $\begin{array}{l}\text { NCEP-ATP } \\
\text { III }\end{array}$ & $\begin{array}{l}\text { Simple random } \\
\text { sampling }\end{array}$ & $\begin{array}{l}\text { February } 28 \text { to May } 30 \\
/ 2017\end{array}$ & 8 \\
\hline
\end{tabular}


medRxiv preprint doi: https://doi.org/10.1101/2020.05.14.20101410; this version posted May 19, 2020. The copyright holder for this preprint (which was not certified by peer review) is the author/funder, who has granted medRxiv a license to display the preprint in perpetuity. All rights reserved. No reuse allowed without permission.

\section{Prevalence of metabolic syndrome}

The current meta-analysis using the random effects model showed that the pooled prevalence of metabolic syndrome in patients with T2DM was $59.62 \%$ (95\% CI: 52.20, 67.03) with substantial level of heterogeneity $\left(\mathrm{I}^{2}=87.8 \%\right.$; $\left.\mathrm{p}<0.001\right)$, (Fig. 2).

Author year
Abban, H.A., et al. (2017)
Adediran, O., et al (2007)
Agyemang-Yeboah, F., et al (2019)
Alebiosu, C.O (2004)
Biadgo, B., et al (2018)
Birarra, M.K etal (2018)

Figure 2. Pooled prevalence of metabolic syndrome in patents with T2DM 
medRxiv preprint doi: https://doi.org/10.1101/2020.05.14.20101410; this version posted May 19, 2020. The copyright holder for this preprint (which was not certified by peer review) is the author/funder, who has granted medRxiv a license to display the preprint in perpetuity.

\section{Subgroup analysis}

To identify the source of heterogeneity across the included studies, subgroup analysis was deployed using publication year, country, diagnostic criteria, and sampling technique Based on the subgroup analysis result, the pooled prevalence of metabolic syndrome was $65.62 \%$ in studies published after 2010, 61.14\% in Ethiopian studies, 64.8\% among studies using NCEP ATP II as a diagnostic criteria, $80.46 \%$ in studies with simple random sampling technique (Table 2).

Table 2. The results of subgroup analysis by different category of the studies

\begin{tabular}{|c|c|c|c|c|c|c|}
\hline Sub-group & Category & $\begin{array}{l}\text { No. of } \\
\text { studies }\end{array}$ & $\begin{array}{l}\text { Sample } \\
\text { size }\end{array}$ & Prevalence $(95 \%$ CI) & p-value & $\mathbf{I}^{2}$ \\
\hline By year & $\leq 2010$ & 11 & 3,759 & $53.17(45.57,60.77)$ & $<0.001$ & $88 \%$ \\
\hline publication & $>2010$ & 12 & 2,723 & $65.62(54.23,77.01)$ & $<0.001$ & $85.5 \%$ \\
\hline \multirow[t]{4}{*}{ Country } & Ethiopia & 4 & 1,153 & $61.14(51.74,70.53)$ & $<0.001$ & $82.9 \%$ \\
\hline & Ghana & 8 & 2,016 & $59.54(42.53,76.56)$ & $<0.001$ & $88.7 \%$ \\
\hline & Nigeria & 7 & 1,996 & $59.27(46.08,72.47)$ & $<0.001$ & $87.5 \%$ \\
\hline & Others & 4 & 1,317 & $58.80(43.42,74.18)$ & $<0.001$ & $87.1 \%$ \\
\hline \multirow[t]{3}{*}{ Diagnostic criteria } & IDF & 8 & 2,582 & $57.15(46.69,67.61)$ & $<0.001$ & $86.8 \%$ \\
\hline & WHO & 5 & 1,113 & $53.12(32.69,73.55)$ & $<0.001$ & $88.2 \%$ \\
\hline & NCEP ATP II & 10 & 2,787 & $64.80(54.74,74.86)$ & $<0.001$ & $87.3 \%$ \\
\hline \multirow[t]{7}{*}{ Sampling technique } & Systematic random & & & & & \\
\hline & sampling & 3 & 834 & $57.91(49.32,66.49)$ & 0.008 & $73.8 \%$ \\
\hline & Simple random & & & & & \\
\hline & sampling & 2 & 724 & $80.46(60.37,100.55)$ & $<0.001$ & $87.9 \%$ \\
\hline & Consecutive & 5 & 1,952 & $62.16(59.93,67.40)$ & 0.07 & $72.6 \%$ \\
\hline & Convenience & 7 & 966 & $60.43(42.34,78.41)$ & $<0.001$ & $87.6 \%$ \\
\hline & Not specified & 6 & 2,006 & $50.29(37.05,63.53)$ & $<0.001$ & $87.5 \%$ \\
\hline
\end{tabular}




\section{Meta regression analysis}

To identify the source(s) of heterogeneity, meta-regression analysis was undertaken by considering year of publication, sample size, diagnostic criteria, country, and sampling technique. However, our results showed that all covariates were not statistically significant for the presence of heterogeneity (Table 4).

Table 3. Meta-regression analysis for the included studies to identify the source(s) of heterogeneity.

\begin{tabular}{lllllll}
\hline Variables & Category & Coef. & $\begin{array}{l}\text { Std. } \\
\text { Err. }\end{array}$ & $\mathbf{t}$ & $\mathbf{P}>|\mathbf{t}|$ & $\begin{array}{l}\text { [95\%Conf. } \\
\text { Interval] }\end{array}$ \\
& & & & & \\
\hline $\begin{array}{l}\text { Sample size } \\
\text { By year of }\end{array}$ & Total sample size & 0.009 & 0.025 & 0.04 & 0.97 & $(-0.051,0.053)$ \\
publication & $>2010$ & & & & & \\
Diagnostic & WHO(reference) & 0.295 & 0.377 & 0.78 & 0.443 & $(-0.489,1.080)$ \\
criterial & IDF & & & & & \\
& NCEP ATP II & 0.098 & 0.595 & 0.16 & 0.871 & $(-1.145,1.341)$ \\
Country & Ethiopia & 0.403 & 0.555 & 0.73 & 0.476 & $(-0.755,1.563)$ \\
& Ghana & 0.169 & 0.693 & 0.01 & 996 & $(-1.448,1.456)$ \\
& Nigeria & -0.053 & 0.592 & -0.09 & 929 & $(-1.293,1.186)$ \\
& Others (reference) & & & & & \\
Sampling & Systematic & 0.115 & 0.729 & 0.16 & 0.876 & $(-1.416,1.647)$ \\
technique & Simple random & 0.562 & 0.518 & 1.09 & 0.292 & $(-0.526,1.650)$ \\
& Consecutive & 0.219 & 0.547 & 0.40 & 0.697 & $(-0.930,1.370)$ \\
& Convenience & 0.101 & 0.627 & 0.16 & 0.873 & $(-1.215,1.419)$ \\
& Not specified (reference) & & & & & \\
\hline
\end{tabular}




\section{Sensitivity analysis}

In sensitivity analyses using the leave-one-out approach, excluding none of the studies had a significant effect on the pooled prevalence estimates and measures of heterogeneity within primary studies. Therefore, sensitivity analyses using the random effects model revealed that no single study influenced the overall prevalence of metabolic syndrome in patient with type $2 \mathrm{DM}$ (Fig. 4).

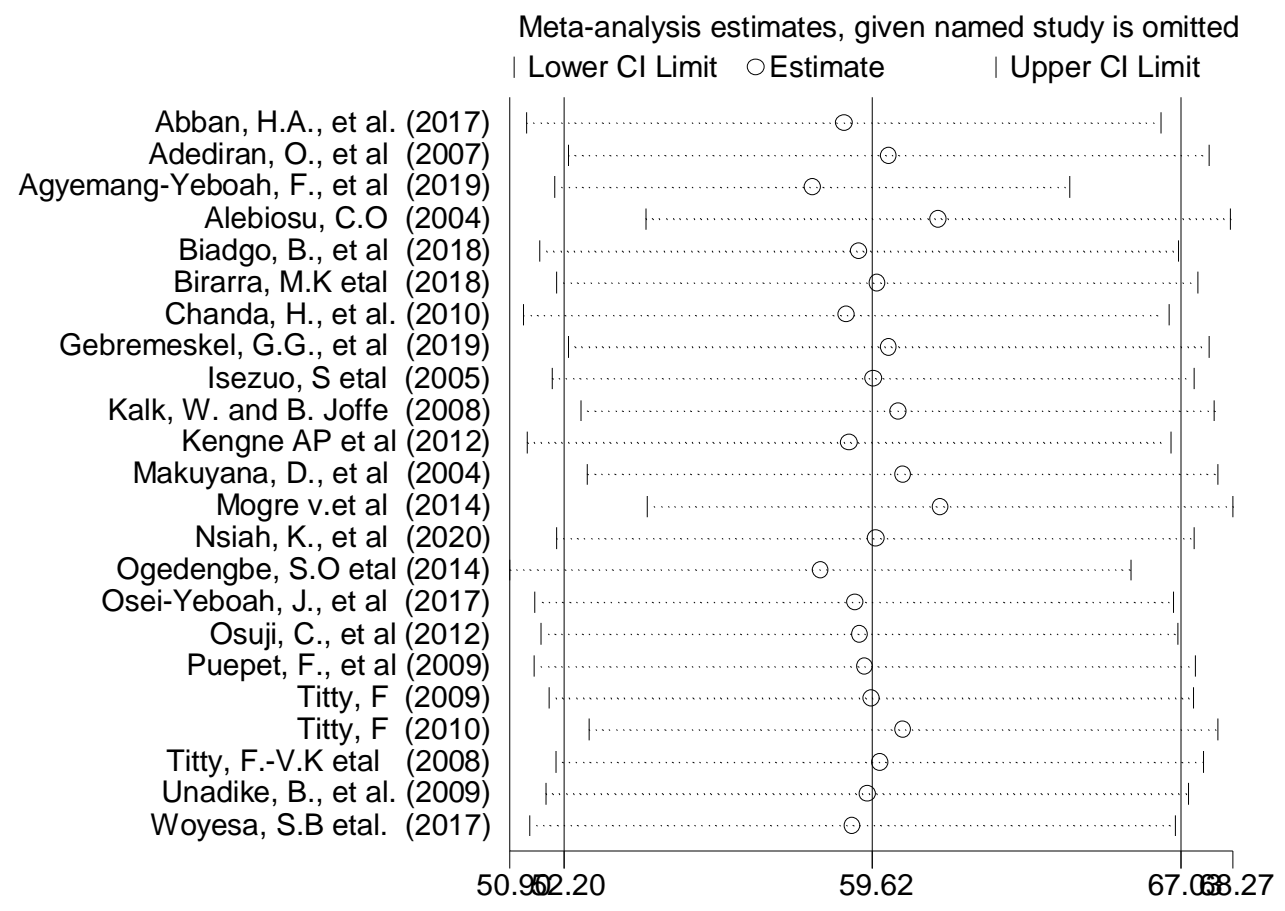

Figure 3. Result of sensitivity analysis of the 23 studies. 


\section{Publication bias}

The visual inspection of the funnel plot showed that there was no publication bias among the included studies, as illustrated by the symmetrical distribution of the funnel plot (Fig. 4). However, the result of Egger test was statistically significant for the presence of publication bias $(\mathrm{P}=0.006)$. Therefore, to reduce and adjust publication bias, trim and fill analysis was performed (Fig. 5). Trim and fill analysis is a nonparametric method for estimating the number of missing studies that might exist [59]. Though we have carried out the pooled prevalence of the MetS after trim and fill analysis, the finding was similar.

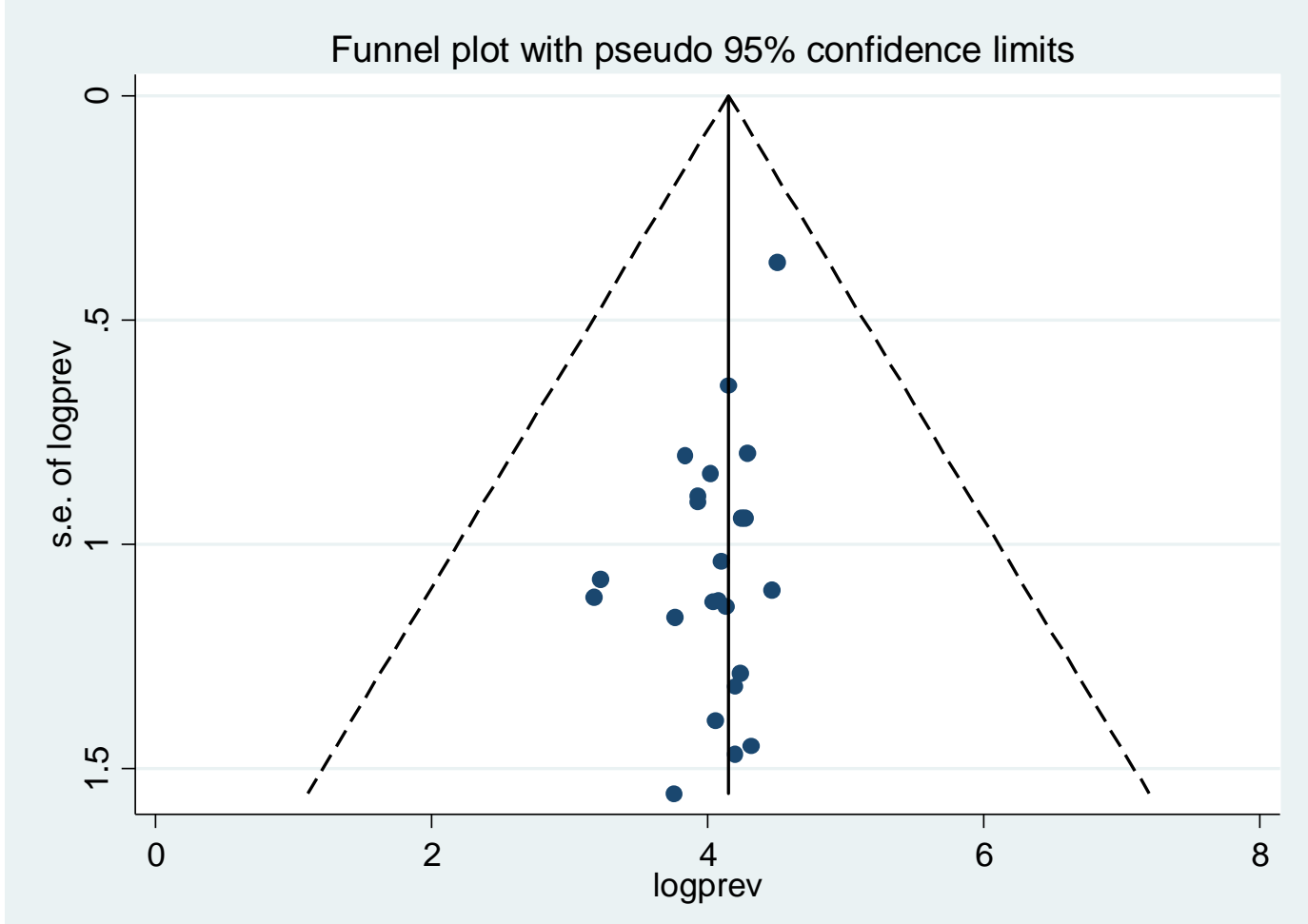

Figure 4. Funnel plot to test publication bias of the 23 studies. 


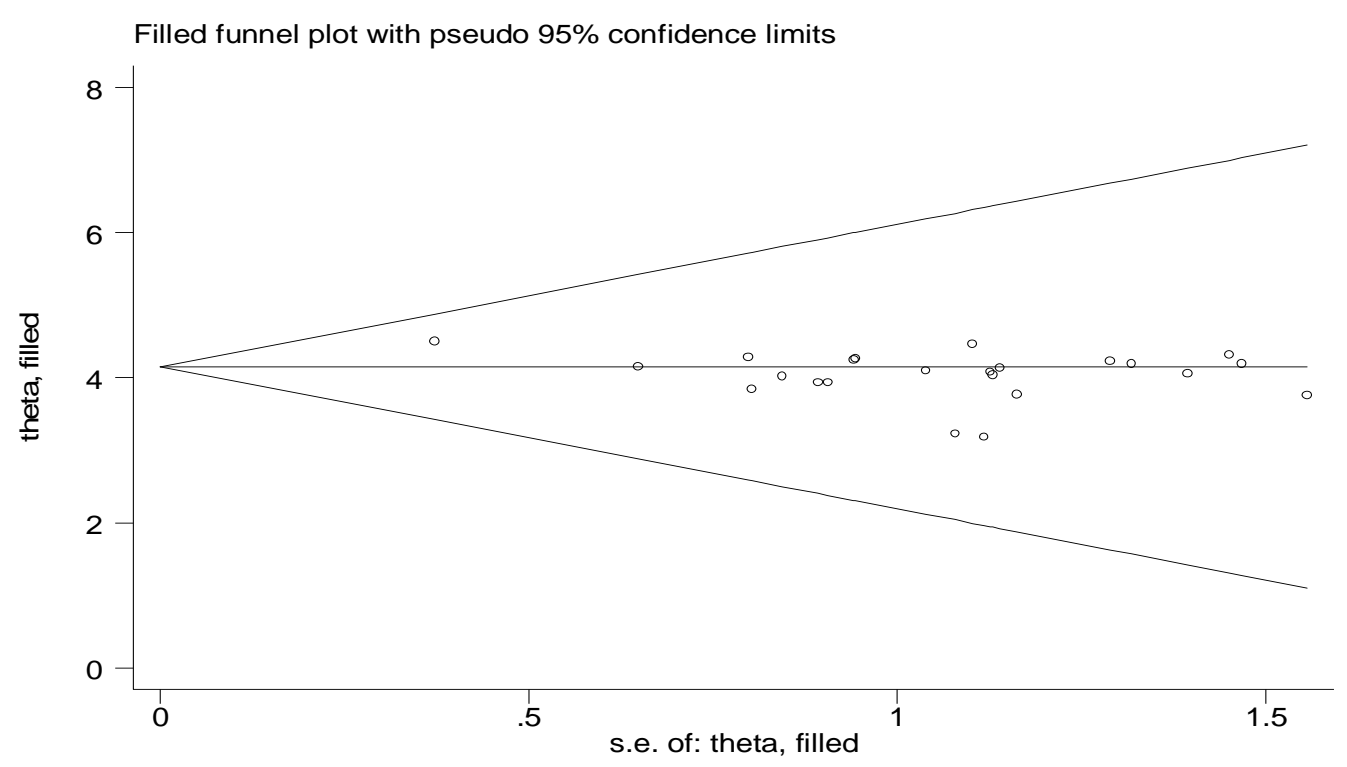

Figure 5. Result of trim and filled analysis for adjusting publication bias of the 23 studies.

\section{Discussion}

In this meta-analysis the pooled prevalence of metabolic syndrome in patients with T2DM in Sub-Saharan Africa was estimated to be 59.62\% (95\% CI: 52.20, 67.03) irrespective of the diagnostic criteria. The overall estimated prevalence of metabolic syndrome among T2DM patients in Sub-Saharan Africa was ranged between $24 \%$ and $90.6 \%$. This result was substantially higher than a systematic review conducted in different European countries where the prevalence ranged between $3 \%$ and $71.7 \%$ [60]. This variation could be justified by difference in diagnostic criteria, variation by ethnicity, possible cultural differences [43], health care seeking behavior's between population, and differences in life style of study participants. In addition, this high prevalence of metabolic syndrome in the SSA could be due to epidemiological transition which has placed them on a double burden of disease, and socioeconomic factors like sedentary lifestyle and eating habits [10, 61].

Based on the subgroup analysis by country, the highest prevalence of metabolic syndrome among T2DM in Sub-Saharan African countries observed in Ethiopia (61.14\% (95\% CI: 51.74, 
medRxiv preprint doi: https://doi.org/10.1101/2020.05.14.20101410; this version posted May 19, 2020. The copyright holder for this preprint (which was not certified by peer review) is the author/funder, who has granted medRxiv a license to display the preprint in perpetuity.

All rights reserved. No reuse allowed without permission.

70.53)), followed by Ghana (59.54\% (95\% CI: 42.53, 76.56)). This variation might be due the difference in the availability of healthcare resources in the countries, and the diagnostic methods used. Based on the diagnostic criteria used (NCEP ATP II, IDF, WHO) across the included studies, the highest prevalence of metabolic syndrome (64.8\% (955CI: 54.74, 74.86)) was reported across studies using the NCEP ATP III diagnostic criteria and the lowest prevalence (53.12\% (95\%CI: 32.69, 73.55)) of metabolic syndrome was reported across studies using the WHOdefinition as a diagnostic criteria. A similar findings in variation of metabolic syndrome prevalence per diagnostic criteria is also reported in a study conducted different European countries, where the prevalence of MetS using NCEP-ATP III criteria ranged from 2\% to 56\%, using IDF ranged from $19 \%$ to $60 \%$, and only $2 \%$ was found based on WHO-definition [60]. Another similar study done Sri Lankan revealed that the prevalence of MetS varied significantly between different diagnostic criteria. They found that the Prevalence of MetS was highest by WHO definition (70\%) followed by IDF (44\%) and NCEP-ATP III (29\%) definitions[62]. These data suggest that while the prevalence of MetS differs between different diagnostic criteria in all populations, the extent of the differences may be larger in some populations than in others [63].

This study has implications for clinical practice. Determining the prevalence of metabolic syndrome among type 2 diabetic patients is critical to guide healthcare professionals to minimize the risk of metabolic syndrome by providing guidance to the patient who has undergone diabetic care follow up. Moreover, it gives information about the burden and public health impact of metabolic syndrome in the region for possible consideration during routine diabetic patient care.

The current meta-analysis has limitations that should be considered in the future research. First, studies from few countries in the sub-Saharan Africa included in this meta-analysis may be difficult to generalize the findings to all type 2 diabetic patients in the region. Second, different criteria used to diagnose metabolic syndrome in the included studies may affect the estimation of the pooled prevalence. Third, this study does not identify the predictors of metabolic syndrome among patients with T2DM.

\section{Conclusion}

Almost two out of three of type 2 diabetic patients in Sub-Saharan African countries have metabolic syndrome, which implies that it is highly prevalent in patients with T2DM. Its 
medRxiv preprint doi: https://doi.org/10.1101/2020.05.14.20101410; this version posted May 19, 2020. The copyright holder for this preprint (which was not certified by peer review) is the author/funder, who has granted medRxiv a license to display the preprint in perpetuity.

All rights reserved. No reuse allowed without permission.

prevalence varies across countries in the region with the highest prevalence in Ethiopia. Therefore, situation-based interventions and country context-specific preventive strategies should be developed to reduce the burden of metabolic syndrome. Further research is needed to identify possible risk factors associated with MetS in patients with T2DM in SSA populations to assist the prevention efforts.

\section{List of abbreviations}

IDF: International diabetic federation; Mets: metabolic syndrome; NCEP ATP II: National Cholesterol Education Program Adult Treatment Panel III; T2DM: type 2 diabetes mellitus; WHO: world health organization.

\section{Declaration}

\section{Ethics approval and consent to participate}

Not applicable.

\section{Consent for publication}

Not applicable.

\section{Availability of data and materials}

All relevant data are within the paper and it's supporting information files. There is no separate data set to share.

\section{Competing interests}

The authors declare that they have no competing interests.

\section{Funding}

Not applicable.

\section{Authors' contributions}

WSS, YAA, WM, and TYA developed the protocol and were involved in the design, selection of study, data extraction, statistical analysis, and developing the initial drafts of the manuscript. 
medRxiv preprint doi: https://doi.org/10.1101/2020.05.14.20101410; this version posted May 19, 2020. The copyright holder for this preprint (which was not certified by peer review) is the author/funder, who has granted medRxiv a license to display the preprint in perpetuity.

All rights reserved. No reuse allowed without permission.

HM, GD, AM, DA, and MG were involved in data extraction, quality assessment, statistical analysis and revising. WSS, YAA, GD, DA, and HM prepared and edited the final draft of the manuscript. All authors read and approved the final draft of the manuscript.

\section{Acknowledgements}

Not applicable

\section{References}

1. Eckel RH, Grundy SM, Zimmet PZ: The metabolic syndrome. The lancet 2005, 365(9468):1415-1428.

2. Eckel RH, Alberti KG, Grundy SM, Zimmet PZ: The metabolic syndrome. The lancet 2010, 375(9710):181-183.

3. Li W-j, Hao X, Kai S, Song X-d, Wang Y-b, Zhen Y-s, Han Y-f, Hui R-t: Cardiovascular risk and prevalence of metabolic syndrome by differing criteria. Chinese medical journal 2008, 121(16):1532-1536.

4. McLELLAN KC BS, Cattalini M, Lerario AC. Type 2 diabetes mellitus, metabolic syndrome and change in lifestyle. Revista de Nutrição. 2007 Oct;20(5):515-24.

5. Alberti KGMM, Zimmet $P$, Shaw J: Metabolic syndrome-a new world-wide definition. A consensus statement from the international diabetes federation. Diabetic medicine 2006, 23(5):469-480.

6. Mbanya JCN, Motala AA, Sobngwi E, Assah FK, Enoru ST: Diabetes in sub-saharan africa. The lancet 2010, 375(9733):2254-2266.

7. Faijer-Westerink HJ, Kengne A-P, Meeks KA, Agyemang C: Prevalence of metabolic syndrome in sub-Saharan Africa: a systematic review and meta-analysis. Nutrition, Metabolism and Cardiovascular Diseases 2019.

8. Nahar S, Rahman M, Ullah M, Debnath B, Sultana N, Farhad C: Prevalence of metabolic syndrome in newly diagnosed type 2 diabetes mellitus. Cardiovascular Journal 2011, 4(1):17-25.

9. Hossain S, Fatema K, Ahmed KR, Akter J, Chowdhury HA, Shahjahan M, Acharyya A, Rahim M, Ali L: Prevalence and determinants of metabolic syndrome among newly diagnosed type 2 diabetic subjects according to different criteria. Diabetes \& Metabolic Syndrome: Clinical Research \& Reviews 2015, 9(2):120-123. 
medRxiv preprint doi: https://doi.org/10.1101/2020.05.14.20101410; this version posted May 19, 2020. The copyright holder for this preprint (which was not certified by peer review) is the author/funder, who has granted medRxiv a license to display the preprint in perpetuity.

All rights reserved. No reuse allowed without permission.

10. Jacob B, George AT, Jose R, Antony T, Sebastain S: Prevalence of metabolic syndrome in newly detected type 2 diabetes mellitus. Academic Medical Journal of India 2015, 3(1):8-12.

11. Isezuo S, Ezunu E: Demographic and clinical correlates of metabolic syndrome in Native African type-2 diabetic patients. Journal of the National Medical Association 2005, 97(4):557.

12. Foroozanfar Z NH, Khanjani N, Bahrampour A, Ebrahimi H. The prevalence of metabolic syndrome according to different criteria and its associated factors in type 2 diabetic patients in Kerman, Iran. Iranian journal of medical sciences. 2015 Nov;40(6):522.

13. Alshkri M, Elmehdawi R: Metabolic syndrome among type-2 diabetic patients in Benghazi-Libya: a pilot study. Libyan Journal of Medicine 2008, 3(4):177-180.

14. Udenze IC AE, Arikawe AP, Egbuagha EU, Onyenekwu C, Ayodele O, Adizua UC. The prevalence of metabolic syndrome in persons with type 2 diabetes at the Lagos University Tteaching Hospital, Lagos, Nigeria. West African journal of medicine. 2013;32(2):126-32.

15. Zimmet PZ, McCarty DJ, De Courten MP: The global epidemiology of non-insulindependent diabetes mellitus and the metabolic syndrome. Journal of Diabetes and its Complications 1997, 11(2):60-68.

16. AlSaraj F, McDermott J, Cawood T, McAteer S, Ali M, Tormey W, Cockburn B, Sreenan S: Prevalence of the metabolic syndrome in patients with diabetes mellitus. Irish journal of medical science 2009, 178(3):309-313.

17. Abd El-Aty M, Mabry R, Morsi M, Al-Lawati J, Al-Riyami A, El-Sayed M: Metabolic syndrome and its components: secondary analysis of the World Health Survey, Oman. Sultan Qaboos University medical journal 2014, 14(4):e460.

18. Isomaa B, Almgren P, Tuomi T, Forsén B, Lahti K, Nissen M, Taskinen M-R, Groop L: Cardiovascular morbidity and mortality associated with the metabolic syndrome. Diabetes care 2001, 24(4):683-689.

19. Unwin N, Gan D, Whiting D: The IDF Diabetes Atlas: providing evidence, raising awareness and promoting action. Diabetes research and clinical practice 2010, 87(1):2-3. 
medRxiv preprint doi: https://doi.org/10.1101/2020.05.14.20101410; this version posted May 19, 2020. The copyright holder for this preprint

(which was not certified by peer review) is the author/funder, who has granted medRxiv a license to display the preprint in perpetuity.

All rights reserved. No reuse allowed without permission.

20. Yadav D, Mahajan S, Subramanian SK, Bisen PS, Chung CH, Prasad G: Prevalence of metabolic syndrome in type 2 diabetes mellitus using NCEP-ATPIII, IDF and WHO definition and its agreement in Gwalior Chambal region of Central India. Global journal of health science 2013, 5(6):142.

21. Foroozanfar Z, Najafipour H, Khanjani N, Bahrampour A, Ebrahimi H: The prevalence of metabolic syndrome according to different criteria and its associated factors in type 2 diabetic patients in Kerman, Iran. Iranian journal of medical sciences 2015, 40(6):522.

22. Tan MC, Ng OC, Wong TW, Joseph A, Chan YM, Hejar AR: Prevalence of metabolic syndrome in type 2 diabetic patients: a comparative study using WHO, NCEP ATP III, IDF and Harmonized definitions. Health 2013, 2013.

23. Kim TH KD, Lim S, Jeong IK, Son HS, Chung CH, Koh G, Lee DH, Won KC, Park JH, Park TS. Prevalence of the metabolic syndrome in type 2 diabetic patients. Korean Diabetes Journal. 2009 Feb 1;33(1):40-7.

24. Adediran O, Edo A, Jimoh A, Ohwovoriole A: Prevalence of the metabolic syndrome among Nigerians with type 2 diabetes. Diabetes Int 2007, 15(1):13-14.

25. Kalk W, Joffe B: The metabolic syndrome, insulin resistance, and its surrogates in African and white subjects with type 2 diabetes in South Africa. Metabolic syndrome and related disorders 2008, 6(4):247-255.

26. Chanda H, Kelly P, Andrews B, Siziya S, Lakhi S: Predictive value of Metabolic Syndrome components in detecting the syndrome in patients with type 2 Diabetes Mellitus. Medical Journal of Zambia 2010, 37(3):130-135.

27. Makuyana D, Gomo Z, Munyombwe T, Matenga J, Hakim J: Metabolic syndrome disorders in urban black Zimbabweans with type 2 Diabetes mellitus. 2004.

28. Abagre TA: Metabolic syndrome among people with type 2 diabetes mellitus in two selected hospitals in the Brong Ahafo Region. University of Ghana; 2016.

29. Woyesa SB, Hirigo AT, Wube TB: Hyperuricemia and metabolic syndrome in type 2 diabetes mellitus patients at Hawassa university comprehensive specialized hospital, South West Ethiopia. BMC endocrine disorders 2017, 17(1):76. 
medRxiv preprint doi: https://doi.org/10.1101/2020.05.14.20101410; this version posted May 19, 2020. The copyright holder for this preprint (which was not certified by peer review) is the author/funder, who has granted medRxiv a license to display the preprint in perpetuity.

All rights reserved. No reuse allowed without permission.

30. Group IETFC: International Diabetes Federation: The IDF consensus worldwide definition of the metabolic syndrome. $\underline{h t t p: / / w w w}$ idf org/webdata/docs/Metabolic_syndrome_def pdf 2005.

31. Organization WH: Definition, diagnosis and classification of diabetes mellitus and its complications: report of a WHO consultation. Part 1, Diagnosis and classification of diabetes mellitus. In.: Geneva: World health organization; 1999.

32. Grundy SM: Third report of the National Cholesterol Education Program (NCEP) expert panel on detection, evaluation, and treatment of high blood cholesterol in adults (Adult Treatment Panel III) final report. Circulation 2002, 106:3143-3421.

33. Shea BJ RB, Wells G, Thuku M, Hamel C, Moran J, Moher D, Tugwell P, Welch V, Kristjansson E: AMSTAR 2: a critical appraisal tool for systematic reviews that include randomised or non-randomised studies of healthcare interventions, or both. bmj 2017, 358:j4008.

34. Modesti PA, Reboldi G, Cappuccio FP, Agyemang C, Remuzzi G, Rapi S, Perruolo E, Parati G: Panethnic differences in blood pressure in Europe: a systematic review and meta-analysis. PloS one 2016, 11(1):e0147601.

35. Hoy D, Brooks P, Woolf A, Blyth F, March L, Bain C, Baker P, Smith E, Buchbinder R: Assessing risk of bias in prevalence studies: modification of an existing tool and evidence of interrater agreement. Journal of clinical epidemiology 2012, 65(9):934939.

36. Huedo-Medina TB, Sánchez-Meca J, Marín-Martínez F, Botella J: Assessing heterogeneity in meta-analysis: Q statistic or $\mathbf{I}^{2}$ index? Psychological methods 2006, 11(2):193.

37. Higgins J, Green S: Assessing risk of bias in included studies. Cochrane Handbook for Systematic Reviews of Interventions Version 5.1. 0; 2011. 2008.

38. Egger M, Davey-Smith G, Altman D: Systematic reviews in health care: meta-analysis in context: John Wiley \& Sons; 2008.

39. Borenstein M, Hedges LV, Higgins JP, Rothstein HR: A basic introduction to fixed-effect and random-effects models for meta-analysis. Research synthesis methods 2010, 1(2):97-111.

40. 2015. SSSSRCSSL. 
medRxiv preprint doi: https://doi.org/10.1101/2020.05.14.20101410; this version posted May 19, 2020. The copyright holder for this preprint (which was not certified by peer review) is the author/funder, who has granted medRxiv a license to display the preprint in perpetuity. All rights reserved. No reuse allowed without permission.

41. Liberati A, Altman DG, Tetzlaff J, Mulrow C, Gøtzsche PC, Ioannidis JP, Clarke M, Devereaux PJ, Kleijnen J, Moher D: The PRISMA statement for reporting systematic reviews and meta-analyses of studies that evaluate health care interventions: explanation and elaboration. PLoS medicine 2009, 6(7):e1000100.

42. Agyemang-Yeboah F, Eghan BAJ, Annani-Akollor ME, Togbe E, Donkor S, Oppong Afranie B: Evaluation of metabolic syndrome and its associated risk factors in type 2 diabetes: a descriptive cross-sectional study at the Komfo Anokye Teaching Hospital, Kumasi, Ghana. BioMed research international 2019, 2019.

43. Mogre V, Salifu ZS, Abedandi R: Prevalence, components and associated demographic and lifestyle factors of the metabolic syndrome in type 2 diabetes mellitus. Journal of Diabetes \& Metabolic Disorders 2014, 13(1):80.

44. Gebremeskel GG, Berhe KK, Belay DS, Kidanu BH, Negash AI, Gebreslasse KT, Tadesse DB, Birhanu MM: Magnitude of metabolic syndrome and its associated factors among patients with type 2 diabetes mellitus in Ayder Comprehensive Specialized Hospital, Tigray, Ethiopia: a cross sectional study. BMC research notes 2019, 12(1):603.

45. Biadgo B, Melak T, Ambachew S, Baynes HW, Limenih MA, Jaleta KN, Tachebele B, Melku M, Abebe M: The prevalence of metabolic syndrome and its components among type 2 diabetes mellitus patients at a tertiary hospital, northwest Ethiopia. Ethiopian journal of health sciences 2018, 28(5).

46. Birarra MK, Gelayee DA: Metabolic syndrome among type 2 diabetic patients in Ethiopia: a cross-sectional study. BMC cardiovascular disorders 2018, 18(1):149.

47. Abban HA, Barnes P, Asante D-B, Effah-Yeboah E, Nsiah P, Fenuku S: Prevalence of metabolic syndrome among diabetes patients in central regional hospital, cape coast, Ghana. Journal of Food and Nutrition Sciences 2017, 5(2):34-43.

48. Nsiah K, Shang VO, Boateng KA, Mensah F: Prevalence of metabolic syndrome in type 2 diabetes mellitus patients. International Journal of Applied and Basic Medical Research 2015, 5(2):133.

49. Osei-Yeboah J, Owiredu WK, Norgbe GK, Yao Lokpo S, Gyamfi J, Alote Allotey E, Asumbasiya Aduko R, Noagbe M, Attah FA: The prevalence of metabolic syndrome 
medRxiv preprint doi: https://doi.org/10.1101/2020.05.14.20101410; this version posted May 19, 2020. The copyright holder for this preprint (which was not certified by peer review) is the author/funder, who has granted medRxiv a license to display the preprint in perpetuity. All rights reserved. No reuse allowed without permission.

and its components among people with type 2 diabetes in the ho municipality, Ghana: a cross-sectional study. International journal of chronic diseases 2017, 2017.

50. Titty F: Incidence and major metabolic risk factors of metabolic syndrome in type 2 diabetic out-patients visiting tamale teaching hospital in Ghana. Ghana Journal of Science 2009, 49:71-76.

51. Titty F: Glycaemic control, dyslipidaemia and metabolic syndrome among recently diagnosed diabetes mellitus patients in Tamale Teaching Hospital, Ghana. West African journal of medicine 2010, 29(1).

52. Titty F-VK, Owiredu W, Agyei-Frempong M: Prevalence of metabolic syndrome and its individual components among diabetic patients in Ghana. Journal of Biological Sciences 2008, 8(6):1057-1061.

53. Alebiosu CO, Odusan BO: Metabolic syndrome in subjects with type-2 diabetes mellitus. Journal of the National Medical Association 2004, 96(6):817.

54. Ogedengbe SO, Ezeani IU: Profile of metabolic abnormalities seen in patients with type 2 diabetes mellitus and their first degree relatives with metabolic syndrome seen in Benin City, Edo state Nigeria. Journal of Diabetes \& Metabolic Disorders 2014, 13(1):61.

55. Osuji C, Nzerem B, Dioka C, Onwubuya E: Metabolic syndrome in newly diagnosed type 2 diabetes mellitus using NCEP. ATP III, the Nnewi experience. Nigerian journal of clinical practice 2012, 15(4):475-480.

56. Puepet F, Uloko A, Akogu I, Aniekwensi E: Prevalence of the metabolic syndrome among patients with type 2 diabetes mellitus in urban North-Central Nigeria. African Journal of Endocrinology and Metabolism 2009, 8(1):12-14.

57. Unadike B, Akpan N, Peters E, Essien I, Essien O: Prevalence of the metabolic syndrome among patients with type 2 diabetes mellitus in Uyo, Nigeria. African Journal of Endocrinology and Metabolism 2009, 8(1):9-11.

58. Kengne AP LS, Sobngwi E, Djouogo CF, Nouedoui C. Metabolic syndrome in type 2 diabetes: comparative prevalence according to two sets of diagnostic criteria in subSaharan Africans. Diabetology \& metabolic syndrome. 2012 Dec 1;4(1):22. 
59. Shi L, Lin L: The trim-and-fill method for publication bias: practical guidelines and recommendations based on a large database of meta-analyses. Medicine 2019, 98(23).

60. Kwasny C, Manuwald U, Kugler J, Rothe U: Systematic review of the epidemiology and natural history of the metabolic vascular syndrome and its coincidence with type 2 diabetes mellitus and cardiovascular diseases in different European countries. Hormone and Metabolic Research 2018, 50(03):201-208.

61. Okafor CI: The metabolic syndrome in Africa: current trends. Indian journal of endocrinology and metabolism 2012, 16(1):56.

62. Herath $\mathrm{H}$, Weerasinghe $\mathrm{N}$, Weerarathna $\mathrm{T}$, Amarathunga A: A comparison of the prevalence of the metabolic syndrome among Sri Lankan patients with type 2 diabetes mellitus using WHO, NCEP-ATP III, and IDF definitions. International journal of chronic diseases 2018, 2018.

63. Mansour AA: The prevalence of metabolic syndrome among patients with type 2 diabetes mellitus in Basrah. Middle East Journal Family Medicine 2007, 5:20-22. 